\title{
FACTORS INFLUENCING THE GROWTH OF CRAFT BUSINESS IN BOGOR CITY
}

\author{
Arini Murwindarti ${ }^{1}$ \\ 1Urban and Regional Planning Study Program, School of Architecture, Planning, and Policy \\ Development, Institut Teknologi Bandung, Bandung 40116, Indonesia
}

Email corresponding: arini@sappk.itb.ac.id

\begin{tabular}{|c|c|c|}
\hline Submitted: & Accepted: & Published: \\
12-07-2021 & $14-07-2021$ & $30-09-2021$ \\
\hline
\end{tabular}

\begin{abstract}
Bogor City has been the tourist destination for a long time, making this sector as the leading sector for the city. Tourism activities in Bogor City encourage the growth of creative industry especially craft business that reap the benefit through direct sales to the tourists as souvenirs. Many argue that unlike other industry in the economy, there are factors that influence the growth of creative industry beside factors of production. This study aims to identify factors that are significantly influencing the growth of craft business in Bogor City. Multiple regression analysis was used to analyze data collected through interviews with 35 owners of craft business which randomly selected from the sample framework. The data obtained including (1) number of workers, (2) capital, (3) raw materials, (4) showroom ownership, (5) participation in exhibitions, (6) business permit ownership, (7) market orientation, and (8) production quantity. The first three data correspond with factors of production in classical economy, while the rest are related to the characteristics of creative-cultural industry. The result shows that none of the variables related to the classical economy factors of production are statistically significant in this model, instead the variables that are related to characteristics of creative-cultural industry are significant. Among other significant variables, participation in exhibition is the most significant variable in affecting the growth of craft business in Bogor City.
\end{abstract}

Key words: craft business, creative class, creative industry

\section{Introduction}

The most prominent contribution of economic geography in regional development is probably its objective to identify factors that influence economic growth of a region. In classical economy, the existence of factors of production such as natural resources, labor/human resources, and capital would lead to economic growth. Richard Florida (2002a) in his book titled The Rise of the Creative Class added creative class as the subset of human resources as the driving force for economic growth. Creative class is a socioeconomic class consisting of people who carry out economic activities which are now referred to as the creative industries (Florida, 2002b).

The term of creative industry was first introduced in England around 1997 as the industries which rely on individual creativity, skill, talent, and intellectual property as the source of wealth and job creation (Thomas et al., 2010). Being born in the United Kingdom, the study of creative industry then spread to the continent, resulted in many researchers trying to investigate the extent to which factors related to the creative class play a role in economic growth. Stam et al. (2008) argue that there is no direct relation between the number of creative business to economic growth, therefore variables are needed to explain the relationship. Stam et al. (2008) use innovation to proxied economic growth triggered by creative industries, whereas Clifton (2008) use quality of place indicators to understand the creative class. Siswanto and Santoso (2016) found that innovation, infrastructure, and the quality of creative products are important among other factors for developing creative industry, while Asmorowati (2013) stated that the firm of creative indusries developed mainly because of the owner's decisions as creative people.

In a study of Indonesian cultural economy, Gibson and Wiszniewski (2004) pointed out that Indonesia's cultural-related or creative products were dominated by manufacturing products (e.g. crafts) rather than intellectual content. Tourism activities provides a significant market to craft business through direct sales to the tourists (Phillips et al., 2017). Therefore, the craft business thrives in tourist destinations, such as Bogor City. Unlike the neighboring cities in Greater Jakarta which dominated by manufacturing sector, Bogor City emerged as tourist and leisure destination. Known for the famous Botanical Garden, culinary, and crafts, the 
number of tourists in Bogor City increased every year. In 2016, more than five million tourists come to Bogor City for leisure and recreation, 96\% of them are domestic tourists (Disbudpar Kota Bogor, 2017). Moreover, crafts have been one of the leading creative industry sub-sectors in Bogor City along with fashion and cullinary (Bappeda Kota Bogor, 2012).

There are four aspects of creative-cultural industries, such as craft business, that differentiate them from other industries in the economy, including the nature of output produced, firm types, behavioral characteristics of firm, and employment aspects (Throsby, 2008). This study tries to explore whether the growth of craft business in Bogor City influenced by factors related to the creative-cultural characteristics mentioned above rather than factors of production in other industries. The paper will be elaborated in three main parts: introduction, methods, and result and discussion. The methods section gives detail about variables, data, and technique used in analyzing the data. The result and discussion focused on answering the research questions: What are the characteristics of craft business in Bogor City? What factors are significantly influencing the growth of craft business in Bogor City?

\section{Methods}

This study was carried out in Bogor City, West Java, Indonesia. As a city that relies on creative industries and tourism, Bogor City has been taking these sectors very seriously. It was stated in the fourth mission of Bogor City: 'to make Bogor a service and tourism city that build upon creative economy'. There are 88 craft businesses in Bogor City registered in 2016 by Dekranasda (Dewan Kerajinan Daerah/ Regional Craft Council) of Bogor City. Dekranasda is a forum led by the governor's wife for craft entrepreneurs to communicate and develop their potentials. Every year Dekranasda collected data from the members to be compiled in The Book of Bogor City Craft Industry Profile which produced annually for internal audiences. This research used the book as the primary secondary data source, since it contains basic information of craft business in Bogor City such as the name and address of each craft business, products, production quantity, revenue, and number of workers.

The data for quantitative statistical analysis were collected through interviews with 35 owners of craft business which randomly selected from the sample framework. There are at least 8 kinds of data obtained from the interview, including (1) number of workers, (2) capital, (3) raw materials, (4) showroom ownership, (5) participation in exhibitions, (6) business permit ownership, (7) market orientation, and (8) production quantity. The first three data correspond with factors of production in classical economy, while the rest try to capture the characteristics of creative-cultural industry stated by Throsby (2008).

The data were analyzed using descriptive statistics and multiple regression analysis. Descriptive statistics were used to describe the characteristics of the craft industry in Bogor City, including the number and types of craft business, as well as its characteristics. Multiple regression analysis was used to assess the relationship between dependent variable and independent variables. In this study, data on production growth was assigned as the dependent variable, while the independent variable consist of 7 continuous and categorical data, defined as in the equation below.

$y=a+b_{1} x_{1}+b_{2} x_{2}+b_{3} x_{3}+b_{4} x_{4}+b_{5} x_{5}+b_{6} x_{6}+b_{7} x_{7}$

Explanation:

$y=$ Production Growth

$a=$ Constant (value of $\mathrm{Y}$ if $\mathrm{x}=0$ )

$b \quad=$ Regression Coefficient

$x=$ Independent Variable Value

$1=$ Number of workers

2 = Amount of Capital

$3=D$ Raw Material

$4=D$ Showroom Ownership

5 = Participation in Exhibition

$6=D$ Business Permits Ownership

$7=D$ Market Orientation

Data of production growth were obtained from interview with craft business owners by asking the production quantity in current year (2016) and the previous year (2015). The continuous data consist of number of workers, amount of capital, and participation in exhibitions. The number of workers refers to how many people are working excluding the owner. The amount of capital meaning how much money invested to the business to be productive in one year. Participation in exhibition is how often a craft business participated in exhibition in one year. All the variables coded $D$ in the equation are dummy variables for categorical data. Data on raw materials shows whether the business uses local raw materials as main materials for producing craft. Since this is categorical data, it needs to be coded as dummy variable, the value of 1 meaning that the business mainly uses local raw materials. Data on market orientation shows whether the business have been selling their product outside 
Bogor City. The value of 1 indicates that the business has broader market orientation, to outside Bogor City or even international market. The value of 1 in data of business permit and showroom ownership indicates that the business has business permit and/or showroom.

The result of regression analysis is interpreted in four steps. The first is to determine how well the model fits by looking to the R-square value, the second is to identify the influence of all independent variables simultaneously by looking at the $\mathrm{F}$ value, the third is to identify the influence of each independent variable by looking at the $T$ value, and the fourth is predicting the growth of production using the model produced.

\section{Results and Discussions \\ Characteristics of Craft Business}

There are 88 units of craft businesses located in Bogor City (Dekranasda Kota Bogor, 2016) producing many kinds of crafts from different types of raw materials, consisting of: fabric/yarn, wood/bamboo, recycling craft, batik, leather, stone, flora, metal, clay, glass, and fleece as (Figure 1). The diagram shows that craft businesses in Bogor City mainly using fabric/yarn and wood/bamboo as the main raw materials, with the percentage of $31 \%$ for fabric/yarn and $22 \%$ for wood/bamboo. Another $47 \%$ are amongst crafts from recycled materials, batik, leather, flora, stone, metal, clay, glass, and fleece, respectively from the highest percentage.

Figure 1. Graph of types of crafts (left) and craft product from recycled materials (right)
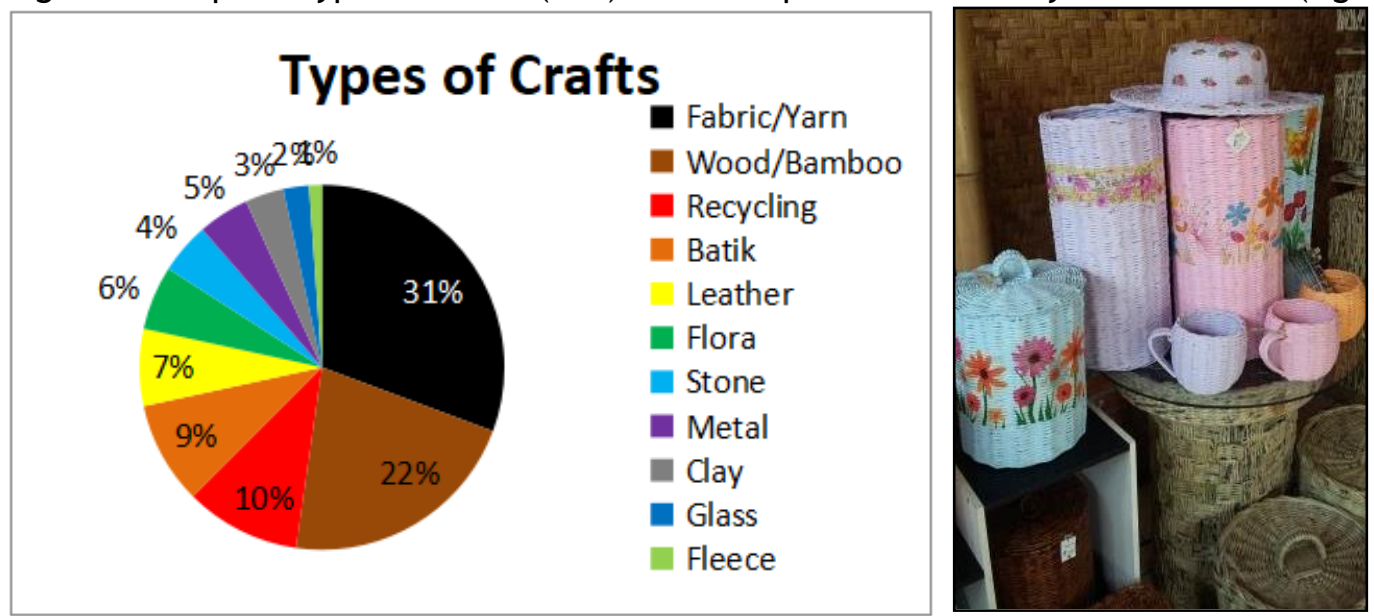

(Source: Dekranasda, 2016)

Jakob et al. (2015) introduced classification of crafts based on its traditionality, which are traditional craft, heritage craft, contemporary craft, and innovative craft. The difference of craft's traditionality can be seen in the toptwo crafts in Bogor City which made from fabric/yarn craft and wood/bamboo craft. Fabric/yarn craft consist of craft made by sewing and knitting process, as well as embroidery and patchwork. Although Indonesia has been famous for its traditional weaving crafts, in Bogor City the types of crafts made from fabrics/yarn are not belong to that category. They are rather modern and does not require indigenous materials and craftsmanship to produce such as embroidery and accessories. On the other hand, wood/bamboo craft can be characterized as traditional and heritage craft since it used only local materials and require local/indigenous craftsmanship such as the maker of wayang golek (West Java traditional puppet).

A total of 35 respondents from 11 types of craft in Bogor participated in this study. Table 1 demonstrates the characteristics of craft business owners in terms of their gender, age, education, and occupation. It can be seen that the number of craft business owners based on gender is almost equal $(48.57 \%$ male and $51.42 \%$ female), therefore there are more female than male. The age of the craft business owners ranged from 20 to above 60 years, where the age group of 20 to 45 years had the most members (74.28\%). The majority of craft business owners had a bachelor education (68.57\%) and high school graduates. In addition, most of the owners (71.42\%) did not have other occupation besides the craft business, while $28.58 \%$ are still working on another job. 
Table 1. The Characteristics of Craft Business Owners in Bogor City

\begin{tabular}{llcc}
\hline \multicolumn{1}{c}{ Characteristics } & Classification & Freq & $\%$ \\
\hline Gender & Male & 17 & 48.57 \\
& Female & 18 & 51.42 \\
\hline Age Group & $20-45$ & 26 & 74.28 \\
& $46-60$ & 8 & 22.86 \\
& $>60$ & 1 & 2.86 \\
\hline Education & Elementary School & 0 & 0 \\
& Junior High School & 0 & 0 \\
& High School & 8 & 22.86 \\
& Bachelor & 24 & 68.57 \\
& Master/Doctor & 3 & 8,57 \\
\hline \multirow{2}{*}{ Other Occupation (Beside Craft) } & Yes & 10 & 28.58 \\
& No & 25 & 71.42 \\
\hline
\end{tabular}

Source: Research Results, 2020

The other characteristics that considered in this study is the inputs, process, output of production, and marketing. Based on the data of the number of workers and revenues, it can be concluded that most of craft business unit in Bogor is mainly characterized as micro, small, and medium enterprises (Law no. 20 of 2008 about Micro, Small and Medium Enterprises) with less than 100 workers and less than Rp 300 million per year in revenue.

The majority $(62.86 \%)$ of craft business unit has relatively small capital (less than $\mathrm{Rp} 50$ million) and used raw material from local area (71.43\%). In terms of production patterns, more than half $(65.71 \%)$ of craft business unit in Bogor producing on a regular basis even though many of them $(65.71 \%)$ also only produce less than one thousand pieces per month, which is small amount of production. Based on how to market the products, most of the business unit $(65.71 \%)$ sells their own products on the store (offline) because most of them $(51.43 \%)$ already have their own store, and some of them $(34.28 \%)$ sell their product in the workshop. In addition, the majority of the business unit $(82.86 \%)$ only serve local market or within the city, and no craft business unit has an international market orientation yet.

Table 2. The Characteristics of Craft Business Unit in Bogor City

\begin{tabular}{llcc}
\hline \multicolumn{1}{c}{ Characteristics } & \multicolumn{1}{c}{ Classification } & Freq & $\%$ \\
\hline Capital (million) & $<$ Rp 50 & 22 & 62.86 \\
& Rp 50 - 200 & 10 & 28.57 \\
& $>$ Rp 200 & 3 & 8.57 \\
\hline Origin of Main Raw Materials & Local & 25 & 71.43 \\
& National & 9 & 25.71 \\
& International & 1 & 2.86 \\
\hline Number of Workers (people) & $1-4$ (Micro) & 9 & 25.71 \\
& $5-9$ (Small) & 13 & 37.14 \\
& $10-100$ (Medium) & 13 & 37.14 \\
\hline Production Pattern & Periodically & 23 & 65.71 \\
& By request & 12 & 34.29 \\
\hline Number of Production (pcs/month) & $<1000$ & 23 & 65.71 \\
& $1000-4000$ & 9 & 25.71 \\
& $>4000$ & 3 & 8.57 \\
\hline Revenue (Rp per year) & $<$ Rp 300 million & 18 & 51.43 \\
& Rp 300 million - 2.5 & 16 & 45.71 \\
& trillion & 1 & 2.86 \\
\hline
\end{tabular}

Source: Research Results, 2020

\section{Factors influencing Craft Business Growth}

This section will explain the result of multiple regression analysis to answer the question about the relationship between multiple independents variable and the growth of production. Table 3 shows that all of the independent variables have tolerance value of more than 0.1 and VIF value less than 5 , therefore there is no multicollinearity problem. The regression model R-squared value is 0.604 . It indicates a good level of prediction (more than $50 \%$ ), which means that the independent variables used in this study explain $60,4 \%$ of the variability of the growth 
of craft production.

The $F$ value tests whether independent variables simultaneously affecting the growth of production. $F$ value in the model $(4,956)$ is higher than the critical value $(2,32)$, meaning that the independent variables (number of workers, capital, raw materials, showroom ownership, participation in exhibitions, business permit ownership, and market orientation) simultaneously affecting production growth. The significance value of 0.001 (less than 0.05) also showed that all independent variables are simultaneously affecting production growth of craft business in Bogor City.

Table 3. Regression Results (Dependent Variable: Production Growth)

\begin{tabular}{clcccccc}
\hline Symbol & \multicolumn{1}{c}{ Independent Variables } & B & Std. Error & T & Sig. & Toll & VIF \\
\hline & (constant) & 24,845 & 8,609 & 2,886 & 0,008 & & \\
\hline$X_{1}$ & Number of Workers & $-0,828$ & 0,549 & $-1,506$ & 0,144 & 0,579 & 1,726 \\
\hline$X_{2}$ & Amount of Capital & $-3,509^{-8}$ & 0,000 & $-0,662$ & 0,514 & 0,523 & 1,912 \\
\hline$X_{3}$ & D Raw Materials & 4,409 & 9,754 & 0,452 & 0,655 & 0,724 & 1,382 \\
\hline$X_{4}$ & D Showroom Ownership & 17,720 & 8,268 & 2,143 & 0,042 & 0,824 & 1,214 \\
\hline$X_{5}$ & Participation in Exhibitions & 3,311 & 0,791 & 4,185 & 0,000 & 0,635 & 1,576 \\
\hline$X_{6}$ & D Ownership of Business & $-22,235$ & 8,911 & $-2,495$ & 0,019 & 0,735 & 1,361 \\
& Permits & & & & & & \\
\hline$X_{7}$ & D Market Orientation & $-24,048$ & 9,062 & $-2,654$ & 0,013 & 0,654 & 1,529 \\
\hline F & $\mathbf{4 , 9 5 6}$ & & & & & \\
\hline F Sig. & 0,001 & & & & & \\
\hline R-Square & 0,604 & & & & & \\
\hline
\end{tabular}

The $T$ value and the significance value for each independent variable indicates whether the independent variable partially affecting production growth. The $T$ value in Table 3 shows that the relationship directions between variables are vary. Amount of capital, number of workers, business permit ownership, and business orientation have negative direction towards production growth, while showroom ownership, raw material, and participation in exhibitions are positive. The $\mathrm{T}$ test also resulted in some independent variables which are significantly affecting production growth, including showroom ownership, business permit ownership, business orientation, and participation in exhibitions. Based on the significance value, it is found that the variable of participation in the exhibition have the stronger and positive relationship with production growth. The regression model resulted in this equation pointed out that if other independent variables are constant, the production growth will change by itself at a constant value of 24.84 .

\section{$Y_{\text {Prod }}=24,845+(-0,828)\left(X_{1}\right)+\left(-3,509^{-8}\right)\left(X_{2}\right)+4,409\left(X_{3}\right)+17,720\left(X_{4}\right)+3,311\left(X_{5}\right)+($ $-22,235)\left(X_{6}\right)+(-24,048)\left(X_{7}\right)$}

Based on the $T$ test result, it can be concluded that none of the variables related to the classical economy factors of production are statistically significant in this model, instead the variables that are related to characteristics of creative-cultural industry such as showroom ownership, business permit ownership, business orientation, and participation in exhibitions are significant. This finding is in line with previous research (see Cooke Jr., 2007 and Akinbogun and Ogunduyile, 2009). As for the most significant variable which is the participation of exhibition, the result of Akinbogun and Ogunduyile (2009) also revealed that the government encouragement in organizing exhibitions for the weaver's guild has ensuring the future of mat weaving in Ogotun-Ekiti. This result is supported by the statement of the informants that the exhibitions not only become a place to bring together sellers (craft business) and buyers, but also as a venue to promote the crafts and expand the market.

\section{Conclusions}

Bogor City has been the tourist destination for a long time, making this sector as the leading sector for the city. Tourism activities in Bogor City encourage the growth of creative industry especially craft business that reap the benefit through direct sales to the tourists as souvenirs, or in Bahasa Indonesia called oleholeh. This study resulted in two main findings: the characteristics of craft industry in Bogor City and the relationship between multiple independent variables (number of workers, capital, raw materials, showroom ownership, participation in exhibitions, business permit ownership, and market orientation) and production growth. From the primary data collected through interview with 35 craft business owners, it can be seen that the majority of the crafts produced by the craftsmen in Bogor City are categorized as 
modern or contemporary crafts which does not require indigenous craftsmanship. Based on the data of the number of workers and revenues, it can be concluded that most of craft business unit in Bogor is mainly characterized as micro, small, and medium enterprises with less than 100 workers and revenue less than Rp 300 million per year. The result on the multiple regression analysis indicates that only four independent variables out of 7 independent variables are significantly affecting the production growth: showroom ownership, business permit ownership, business orientation, and participation in exhibitions. It can be concluded that none of the variables related to the classical economy factors of production are statistically significant in this model, instead the variables that are related to characteristics of creative-cultural industry are significant. Among other significant variables, participation in exhibition is the most significant variable in affecting the growth of craft business in Bogor City. Therefore, encouraging craft business owners to participate in exhibitions can be effective strategy in improving the development of craft industries in Bogor City.

\section{References}

Akinbogun, T.L.; Ogunduyile, S.R. (2009). Crafts Engagement in The Economic Survival of South Western Nigerian Rural Women. Journal of Enterprising Communities: People and Places in The Global Economy 3 (2): 217 - 234.

Asmorowati. (2013). Creative Cluster or Creative Class?: A Case Study of Nitiprayan Artist Kampong, Yogyakarta. Tesis. Universitas Gadjah Mada.

Bappeda Kota Bogor. (2012). Kajian Pengembangan Tematik Potensi Ekonomi Kreatif Kota Bogor. Bappeda Kota Bogor. Kota Bogor.

Clifton, Nick. (2008). The "Creative Class" in the UK: An Initial Analysis. Geografiska Annaler Series B, Human Geography 90 (1): $63-82$.

Cooke Jr., Edwar S. (2007). Modern Craft and The American Experience. American Art 21 (1): 2 - 9. The University of Chicago Press on behalf of The Smithsonian Institution.

Dekranasda Kota Bogor. (2016). Buku Profil Pengrajin Dekranasda Bogor. Dekranasda Kota Bogor. Kota Bogor.

Disbudpar Kota Bogor. (2017). Kunjungan Wisatawan ke Kota Bogor.

Florida, Richard. (2002a). The Rise of Creative Class: And How It's Transforming Work, Leisure, Community, and Everyday Life.
New York: Basic Books.

Florida, Richard. (2002b). Bohemia and Economic Geography. Journal of Economic Geography 1 (2): 55 - 71.

Gibson, Chris; Wiszniewski, Iwona. (2004). Indonesia's Cultural Economy: An Economic Geography Using Two Secondary Data Sources. Indonesian Journal of Geography 36 (1): 1 - 24.

Jakob, Doreen; Thomas, Nicola J. (2015). Fire Up Craft Capital: The Renaissance of Craft and Craft Policy in The United Kingdom. International Journal of Cultural Policy DOI: 10.1080/10286632.2015.1068765.

Phillips, Willard; Indar, Dalena; Thorne, Elizabeth. (2017). An Analysis of the Art and Craft Sector and Its Potential for Sustainable Tourism Development in the Caribbean. Santiago: UN ECLAC.

Republik Indonesia. (2008). Undang Undang No. 20 Tahun 2008 tentang Usaha Mikro, Kecil, dan Menengah. Sekretariat Negara. Jakarta.

Republik Indonesia. (2009). Instruksi Presiden Republik Indonesia No. 6 Tahun 2009 tentang Pengembangan Ekonomi Kreatif. Sekretariat Negara. Jakarta.

Siswanto V.K.; Santoso, E.B. (2016). Factors Influencing Creative Industries Development in Kenjeran Surabaya. IOP Conference Series: Earth and Environment Science 79 (012029).

Stam, Eric; de Jong, Jeroen P.J.; Marlet, Gerard. (2008). Creative Industries in The Netherlands: Structure, Development, Innovativeness, and Effects on Urban Growth. Geografiska Annaler Series B, Human Geography 90 (2): 119 - 132.

Thomas, Nicola J.; Hawkins, Harriet; Harvey, David C. (2010). The Geographies of The Creative Industries: Scale, Clusters, and Connectivity. Geography 95 (1): 14 - 21.

Throsby, David. (2008). From Cultural to Creative Industries: The Scientific Characteristics of The Creative Industries. Makalah pada Troisiéme Journées d'Economie de la Culture: Nouvelles Frontiéres de L'Economie de la Culture, Paris. 